\title{
JOHN DEWEY'S EDUCATIONAL THEORY AND EDUCATIONAL IMPLICATIONS OF HOWARD GARDNER'S MULTIPLE INTELLIGENCES THEORY
}

\begin{tabular}{l}
\hline Dr. Elena Achkovska Leshkovska, \\
Dr. Suzana Miovska Spaseva, Instit \\
\\
\hline A R T I C L E I N F O \\
Studies and articles \\
Received: November, 21.2016. \\
Revised: December, 14.2016. \\
Accepted: December, 16.2016. \\
doi:10.5937/IJCRSEE1602057A \\
UDK \\
37.01:929 Гарднер Х. \\
37.01:929 Дјуи Џ. \\
159.953.5 \\
159.922.72
\end{tabular}

Keywords: John Dewey, Howard Gardner,

Education,

Educational theory.

\begin{abstract}
A B S T R A C T
Since 1983, when Howard Gardner published his theory of multiple intelligences, educators have begun to incorporate this new model into school programs. However, the idea of multimodal teaching is hardly a new concept. Many pioneers of modern education, such as: J. J. Rousseau, J.H. Pestalozzi, M. Montessory, J. Dewey, suggested educational models that oppose uniformity and predominantly verbal teaching. The aim of the research presented in this paper is to identify and compare compatible elements of educational ideas of John Dewey and Howard Gardner. The research is based on historical-comparative method and content analysis technique and is focused on exploring three key elements of intersection: curriculum, methods of teaching and learning, and teachers' role. Regarding the curriculum, both authors prefer integrated and thematic curriculum based on real-life context. They also agree on student-centred teaching where implementation of variety of active methods of learning will give opportunity to students to express their specific identity. Teacher's role in both concepts is to link students' personal experiences and characteristics to the material being studied and to the school life in general. The findings imply that educational implications of Gardner's theory can be considered as a continuation of Dewey's progressive vision of classroom teaching and school organization.
\end{abstract}

(C) 2016 IJCRSEE. All rights reserved.

\section{INTRODUCTION}

The American scholars John Dewey and Howard Gardner, although living and working in different epochs, have built theories that initiated educational reforms in the school system in the Unites States and beyond. At the beginning of the 20th century John Dewey sharply criticised the traditional "old school", with a large number of passive students and with uniform curriculum and teaching methods, which

Corresponding Author

Dr. Elena Achkovska Leshkovska. Institute of psychology, Faculty of Philosophy, University Ss. Cyril and Methodius-Skopje, Republic of Macedonia Email: elenaa@fzf.ukim.edu.mk

This work is licensed under a Creative Commons Attribution - NonCommercial - NoDerivs 4.0. The article is published with Open Access at www.ijcrsee.com center of gravity is in the teacher, in the textbook, anywhere and everywhere except in the immediate instincts and activities of the child himself (Dewey, 1915, p. 35). Based on these observations, he created an authentic comprehensive and coherent educational theory that marked the 20th century and dramatically shaped the educational reform process at elementary schools in the United States, but also in Europe and Asia. It promotes a child-centered approach in education, which is founded on several key principles (Dewey, 1915, 1966, 1974c):

- Education is a necessity of life, social process of continuing change and reconstruction of the individual experience; being interpreted within the concept of development, education is a process of living and not a preparation for future living.

- School is an embryonic form of 
community life and an instrument for social change and progress. That means that the school life grows out of all the aspects of the social life and that the child's experience develops in transaction with the community he lives in.

- Activity is the fundamental characteristic of the child's nature, which is expressed through his instincts, experience, interests and individuality. They represent a huge educational potential and starting point of the process of learning, but are not an end in itself: they need to be controlled and guided toward realization of predetermined goals.

Eight decades after Dewey had announced his educational theory, Gardner (1983) introduced the theory of multiple intelligences (MI), challenging the traditional concept of general intelligence as a single entity. On the basis of the neurological and cultural research, he described an individual's cognitive abilities in terms of seven relatively independent but interacting intelligences: linguistic, logical-mathematical, spatial, musical, bodily-kinesthetic, intrapersonal and interpersonal. Later he added the eight, naturalist intelligence, and considered the possibility of including existential one as a ninth. The key points of the concept are: 1 . each person possesses all intelligences, but they function together in ways unique to each person; 2 . most people can develop each intelligence to an adequate level of competency; 3 . intelligences usually work together in complex ways and 4. there are many ways to be intelligent within each category (Armstrong, 1994).

Gardner himself offered very few suggestions for educational use of the MI theory, since psychology does not directly dictate education but, "it merely helps one to understand the conditions within which education takes place" (Smith, 2002, 2008). However, it has had an intense impact on educational practice and during the late 80 's a number of schools in North America have structured curricula according to its key principles. The theory inspired educators to question their work and encouraged them "to suggest approaches to curriculum, pedagogy, assessment, learning differences, use of computers, place of the arts - indeed, almost any issue in which educators are interested" (Gardner, 2011, p. 6). The experience of scholars and practitioners on implementation of MI ideas with various populations, age groups and educational settings was presented in the book Multiple Intelligences Around the World (2009). Of course, along with the good practices, a lot of misinterpretation occurred, that provoke the author to delineate the most common misunderstandings of his theory (Gardner, 1993, p. 68).

Although Gardner didn't create educational theory, he reflected on the different trends and contemporary status of the education in American society. In this context, he emphasized the need of changing the American education toward student-centred teaching: "American education is at a turning point. There are considerable pressures to move very sharply in the direction of "uniform schooling"; there is also the possibility that our educational system can embrace "individual centred schooling" (Gardner, 1993, p. 68). Gardner himself declared that much of his writings on education have been identified with educational tradition of Dewey and so called progressive or neo-progressive movement. He accepted his "alternative educational vision" which is "centred on understanding" so that "an individual understands the concept, skill, theory or domain of knowledge to the extent that he or she can apply it to a new situation" (Gardner, 1999, p. 118-119). In fact, Dewey and Gardner shared the same need for educational reform claiming that the established teaching methods at their times are neither correct nor beneficial for students. Also, both authors' ideas were subject to criticism and unenthusiastic responses along with the positive reactions.

\section{MATERIALS AND METHODS}

The review of the part of the literature written by Howard Gardner and other authors who overview his ideas and their educational implication, shows that on several occasions the relation between Dewey's and Gardner's thoughts on education has been pointed out. Unfortunately, either the elaboration on their common ideas is missing, or there are irreconcilable interpretations of Dewey's influence on Gardner. For example, Armstrong (1994) wrote that "MI theory is perhaps more accurately described as a philosophy of education, an attitude toward learning, or even a metamodel of education in the spirit of John Dewey's ideas...". Berube and Berube (2007, p. 21) declared that "Howard Gardner is another neo-progressive with links to John Dewey... Moreover, Gardner's definition of intelligence 
is a variation of Dewey's."

The lack of analysis of the statements as those mentioned above was the incentive for the study aiming at:

- presenting J. Dewey's key ideas on education;

- presenting key points of implications of H. Gardner's MI theory in educational practice;

- identifying and comparing compatible elements of educational ideas of John Dewey and Howard Gardner.

The method used in the research is historical-comparative and it is carried out through content analysis of several books and scientific papers of both authors, as well as the part of the literature that comment their work. The analysis is focused on exploring three key elements of intersection of both authors' educational ideas: curriculum, methods of teaching and learning, and teachers' role. The material that is subject to analysis is presented in the list of references.

\subsection{Dewey and Gardner's ideas: comparing key educational concepts}

\section{Curriculum \\ Dewey on Curriculum}

Curriculum represents central issue in Dewey's school and key concept in his educational theory. If the starting point is the child who creates his experience in transaction with the surrounding environment, it is understandable why Dewey's concept of curriculum is different from the traditional one, which is perceived as a set of systematized information that is carefully packed in subjects and is independent from the child's experience. Hence, traditional school is separated from the real life and becomes "place for listening"; the knowledge becomes formal, static, and dead, while the child is treated as immature, superficial being with egoistic, impulsive and confused behaviour. Despite the fact that Dewey criticized traditional separation of the curriculum from child's experiential learning, he didn't reject the idea of systematized knowledge. The education should follow the path that leads from child's individual experience towards cumulative experience of the human kind. In this way, the child and the school curriculum build together the unity of the educational process.

Dewey pays great attention to the relationship between the child and the curriculum, trying to overcome the separation between the two fundamental factors in the educational process, between "an immature, undeveloped being and certain social aims, meanings, values incarnate in the matured experience of the adult" (Dewey, 1974a, p. 339-340). This separation leads to three fundamental divergences and elements of conflict: the narrow but personal world of the child against the impersonal but infinitely extended world of space and time; the unity, the single wholeheartedness of the child's life, and the specializations and divisions of the curriculum; an abstract principle of logical classification and arrangement and the practical and emotional bonds of child life (Dewey, 1974a, p. 341-342). According to Dewey, these differences are the basis for developing two opposing educational systems: subject-centered and child-centered education. He strives to unify them, emphasising that there is no gap, but a transaction between the child and the subject matter, because they are simply two limits which define a single process: "Just as two points define a straight line, so the present standpoint of the child and the facts and truths of studies define instruction. It is continuous reconstruction, moving from the child's present experience out into that represented by the organized bodies of truth that we call studies" (Dewey, 1974a, p. 344). Hence, it is obvious that Dewey is not against the organized knowledge in textbooks and curriculum, but that it represents an aim of the learning process, the "final point" that should be reached. Human experience presented in books and textbooks is of great importance for the child, because it "gives direction; it facilitates control; it economizes effort, preventing useless wandering, and pointing out the paths which lead most quickly and most certainly to a desired result" (Dewey, 1974a, p. 350). However, the subject matter is not a substitute for a personal experience, for "an actual journey". It has meaning only if related to the existing experience, providing its stimulation and guidance. The absence of this characteristic, according to Dewey, causes many weaknesses of the traditional school.

When learning is based on experience, it is characterized by continuity and interaction. Unlike the old school where subjects are taught independently of each other in strictly defined time frames, Dewey stands for connection of subject content and flexible duration of classes, allowing the child to follow his interest in the process of learning. Basic skills such as reading and writing, in his opinion, should not be taught as formal subjects, but 
should result from the child's need to master them in order to realize new goals. They represent instruments that every child learn how to use them, in his own pace in accordance with the individual motivation.

In the last years of the 19th century, Dewey observed that "the accumulation of knowledge has become so great that the educational system is disintegrating through the wedges of studies continually introduced" (Tanner, 1997, p.163). The answer to these conditions he finds in developmental curriculum: "All studies arise from aspects of the one earth and the one life lived upon it. We do not have a series of stratified earths, one of which is mathematical, another physical, another historical, and so on... Relate the school to life, and all studies are of necessity correlated" (Dewey, 1915, p. 80-81). Therefore, starting point for teachers in Dewey's school is undifferentiated curriculum that is followed by building conceptual knowledge from different subject arias. What provides the unity of the curriculum and its horizontal and vertical connection are occupations, which keep balance between intellectual and practical phase in the experience.

\section{Gardner on curriculum}

One central question in education is What is to be taught? Is it most important to focus on societal roles, cultural values or various forms of knowledge accumulated over the millennia? Each society value specific capacities and knowledge is encoded in variety of forms. Achieving an appropriate balance of "skilled performance, rich information and deep understanding" is a challenging matter (Gardner, 1991, p. 118). Gardner's interest in 'deep understanding', performance, exploration and creativity are not easily accommodated within an orientation to the 'delivery' of a detailed curriculum planned outside of the immediate educational context. He is convinced that superficial understandings of learners due to the fact that schools attempt to cover a large quantity of material. Instead, it is far more useful to spend more time on key concepts and essential questions and to allow students to become familiar with these notions and their implications.

The linking of students' education with the most up-to-date 'facts' about human intelligence, has great implications for the school setting. Gardner admits that "the idea of a number of relatively independent cognitive abilities is not in itself daunting. What is daunting is the notion that one should therefore change one's pedagogy, curriculum, or means of assessment" (Phillips, 2010, p. 5). MI theorybased curriculum is student-centered, flexible (full of choices) and provide a setting for learning that is hand-on, interdisciplinary, based on real-life contexts, and set in an informal atmosphere that promotes free inquiry into novel materials and situations. Gardner (1999, p. 221) wrote: "Without apology, I confirm that I am a defender of the disciplines" but delivery of the traditional school subjects should be done in non-traditional ways, through projectcentred instruction and extension of students' understanding of the topic by activities in the local community. Thematic and integrative instruction imitates life because it teaches students from an interdisciplinary point of view and provides them with opportunities to use their multiple intelligences in practical ways.

As a proponent of pluralistic approach, Gardner claims that nearly every topic can be approached in several ways: telling of a story, an artistic exploration, experiment or simulation. Since some individuals learn better through stories, others through artistic expression, or hands on activities or group work, each of these approaches activates a distinctive set of intelligences. Approaching a topic from a number of perspectives can be described as "multiple windows leading into the same room." The benefit of pluralization is that more learners will be able to understand something well, in ways that are comfortable for them and "not to leave any student out of the learning loop like the traditional schooling has done" (Phillips, 2010). Because the model is flexible, how it is applied in schools will vary depending on the beliefs and goals of educators. The author of the MI theory states that it is not a collection of rigid scripts that schools must enact in the same way in all settings, nor is it a simplistic cookbook for school improvement; "there are as many plausible recipes as there are educational chefs" (Achkovska Leshkovska, 2002, p. 101). However, Gardner (1995, p. 9) pointed out that he would appreciated school where "differences among youngsters are taken seriously, knowledge about differences is shared with children and parents, children gradually assume responsibility for their own learning, and materials that are worth knowing are presented in ways that afford each child the maximum opportunity to master those materials and to show others (and themselves) what they have learned and understood." 


\section{Dewey and Gardner on curriculum}

On the basis of presented ideas of Dewey and Gardner on curriculum, it is possible to identify several common points of view. Both authors claim that the subject matters should provide links with real-life situations in order students' knowledge to be useful. The starting point of both authors is the child's nature and the need to adjust the curriculum to its individual features. While Dewey is focused on child's present experience and interests as embryos of capacities, Gardner put emphasis on distinctive cognitive profiles that are developed in early childhood and determine the most effective "entry points" for learning. Students' individual differences that are highlighted in Dewey's and Gardner's views, pave the way for flexible curriculum that is set up in an informal atmosphere. According to Dewey, the individualization of the curriculum is done through certain real-life occupations as forms of experiential learning and practical "learning-by-doing" activities. On the other hand, individualization within the educational implications of Gardner's MI theory is achieved through translation of the content into different "language" of each intelligence.

Another meeting point in Dewey's and Gardner's views is integrated curriculum. Gardner relates the implementation of this kind of curriculum to the child's need to get "an overall sense of the world", to integrate different channels of the own complex of intelligences, "for survival could not take place in the absence of some coherent versions of the world" (Gardner, 1991, p. 83). Close to this is Dewey's developmental curriculum that is undifferentiated, because it reflects the primitive unconscious unity of the social life of the child. Unlike Gardner who is not explicitly against division of knowledge in different subjects, Dewey argues that it is a violation of the child's nature if introducing the child too abruptly to a number of specific studies. The student's progress is not "in the succession of studies, but in the development of new attitudes towards, and new interest in, experience" (Dewey, 1974c, p. 434).

\subsection{Learning and teaching methods}

\section{Dewey on learning and teaching meth- ods}

According to Dewey, the method is always in relation with the subject matter, it is not something outside of the material that needs to be studied. The method is "the effective direction of subject matter to desired results" (Dewey, 1966, p. 165), and the effectiveness implies processing of the content with maximum of savings in time and energy. This means that the method is primarily work of mind in dealing with experiential content: "The only method that has meaning is the method of the mind that achieves and assimilates" (Dewey, 1966, p. 127). Hence, when talking about method, Dewey puts emphasis not so much on teaching methods, but on methods of learning and experiencing.

In the process of learning by experience, Dewey says, the starting point is a particular problem situation, because the problem itself is the provocative element in the experience that calls upon the mind and puts it into operation. Having in mind that the development depends on the exposure to difficulties that should be overcome through the engagement of mind (Dewey, 1966b, p. 79), Dewey believes that the key method in the process of learning is problem solving. Problem situations should be connected to actual child experience and within the child's abilities for their resolution. Since earliest ages, children work on projects, individually or in groups, in school laboratories that enables them to develop their intelligence and manipulative skills. The aim of such an activity is not to give students analytical knowledge about the subject, but to stimulate their curiosity and research spirit (process oriented instead of content-oriented). Hence, learning methods should be active and inquiry based and the accumulation of information and principles must be subordinated to the development of intellectual self-control and ability to identify and solve problems.

Experience is the link between the method and the curriculum, between the action and the object upon which it is acted. It is not only a simple combination of mind and world, of method and content, but it is "a single continuous interaction of a great diversity of energies" (Dewey, 1966, p. 167). Isolation of the method and the content, according to Dewey, leads to several anomalies in the school educational process. Considering the fact that the students have very few opportunities for experiential learning, methods that teachers use are not an expression of their own "intelligent observations," but are "authoritatively recommended" and are characterized by "a mechanical uniformity " (Dewey, 1966, p. 168). This means that the method becomes a cut and dried routine of following prescribed steps, rather than 
a creative act and a result of an individual experimentation.

Teaching method, says Dewey, is the method of an art, of action intelligently directed by ends (Dewey, 1966, p. 170). As every artist should be thoroughly acquainted with materials and tools with which he works, so the teacher must be in possess of the methods used by others, which experience has shown to be more efficient in the process of acquiring knowledge. However, knowing or owning these, as Dewey calls them, general methods, is not in opposition to the individual initiative and creativity of the teacher. If they are acquired as intellectual aids in sizing up the needs, resources, and difficulties within the framework of his experience, they are of constructive value (Dewey, 1966, p. 172). At the same time, the method is a result of the individual's specificity and could be understand as various individual methods. They reflect the individual approach to the problem, as well as different abilities, past experiences and interests. Dewey believes that there are several attitudes that are central in the process of intellectual dealing with subject matter: directness or straightforwardness with which one goes at what he has to do, flexible intellectual interest or openness of mind for learning, intellectual integrity, honesty and sincerity, as well as undertaking responsibility for the consequences of the act (Dewey, 1966, p. 173-179).

In Dewey's educational theory, the issue of method is primarily an issue of development of child's powers and interests. It means that the teacher should know well each child's development and follow his interests which are understood as "dawning capacities" (Dewey, 1974c, p. 436). In fact, the method and the way the content will be processed, is to be found in the child's own nature. Thus, considering the fact that the active side precedes the passive in the development of the child's nature ("expression comes before conscious impression; the muscular development precedes the sensory; movements come before conscious sensations ..." (Dewey, 1974c, p. 435), it is necessary to create conditions in the process of education that will allow the child to express its nature regarding the content, as well as the methods of learning and teaching.

\section{Gardner on learning and teaching methods}

One of the basic principal in MI theory is that human beings differ from one another and each person possesses all eight intelligences, but they function together in ways unique to each person. Children begin to show inclinations in specific intelligences from an early age and by the time they enter the school, they have already established ways of learning that are in line with their preferred intelligences. Each intelligence has its own unique symbol or notational system: phonetic, idegraphic, musical notational system etc. Therefore, there is absolutely no reason to teach and assess all individuals in the identical way.

According to Gardner (2011), the most important educational implications of MI theory are individuation and pluralization. Noting that the traditional classrooms stimulate dominantly linguistic and logical-mathematical abilities, Gardner emphasizes the need to expand teachers' repertoire of strategies with ones that nurture each intelligence. Students think and learn in many different ways. Using different methodologies, exercises and activities, teachers will meet needs of all students, not just those who excel at linguistic and logical intelligence. The broad range of techniques provides each student, from time to time, to have opportunity to learn in a way that works best for him/her. However, selection of appropriate methods should be based on solid criteria and critical inquiry on the part of the teacher.

Gardner $(2011$, p. 6) suggested that "in the future, good practice should particularize the modes of presentation as well as the manner of assessment as much as feasible; and that individuation should be based on our understanding of the intellectual profiles of individual learners." Gardner recognizes that it is hard to implement individualization in classroom with large number of students, but in a modern era a learner-centered curriculum is more readily attained because of the availability of computer technology in education settings. Schools can deliberately collect and make available resources- human and technological -that fit comfortably with the disparate learning style and cultural background of each student. (Gardner, 1991, p. 244).

Gardner himself didn't come up with a set of teaching strategies that promote MI philosophy. Rather, the theory offers educators a broad opportunity to creatively adapt its fundamental principles to different educational settings. Some of the teaching techniques have been used for decades by good teachers, the other ones are invented by the teachers themselves. For example, Armstrong (2009) elaborates forty teaching strategies, five for each of the eight intelligences that are designed to 
be general enough to be applied at any grade level.

\section{Dewey and Gardner on learning and teaching methods}

Both authors share same understanding of methods of learning and teaching as tools for development of child's strengths and interests. The method is implicit within the child's own nature, hence it is necessary for the teacher to use a variety of methods that are complementary to the topic and to the student's specific cognitive style and identity. They also agree that learning should not be primarily oriented on products, but on process, and therefore, teachers should use methods that provoke student's higher order thinking instead of mere memorizing the facts.

Unlike Dewey who elaborates the issue of method on a solid theoretical basis, making distinction between general and specific methods and focusing on problem solving situations in the process of learning, Gardner offers only general guidelines that enable teachers to create a vast range of techniques that encourage development of different intelligences. His starting point is that traditional teaching gives priority to methods that stimulate linguistic and mathematical-logical intelligences, and the result is that many students fail to exhibit their strengths in other domains.

\subsection{Teacher's role}

\section{Dewey on teacher's role}

The role of the teacher in Dewey's educational theory is defined within the framework of its understandings of experience and development. The value of the systematized and defined experience of the adult mind, as Dewey points out in his book "The child and the curriculum", is in interpreting the child's life as it immediately shows itself, and in passing on to guidance or direction (Dewey, 1974c, p. 345). Interpretation and guidance of the child are, in fact, the two crucial tasks of the teacher, which require his considerable efforts and engagement.

Teacher primarily needs to know and understand the characteristics of the childhood, but also the nature of each child as individual. To interpret the child's nature, according to Dewey, means to consider his strengths and weaknesses within the process of development and in connection with the dynamic character of the child's experience. Hence, it is wrong approach of the teachers in the "the old" school, which consider the child as an immature being that needs to get rid of this negative trait as soon as possible, in order to move towards the mature adult. On the other side, equally dangerous according to Dewey, is the interpretation of the "new education" that the children's powers and interests are important as such and they should be cherished as they are. Education for Dewey is neither "putting in" as Herbart believes, nor "drawing out" as Froebel defines it. It should be a conscious and intentional activity, which gives direction to the child's activities (Miovska-Spaseva, 2005, p.76-80).

Understanding the child's nature within the framework of continuous development represents a basis for his guidance or directing. In order to be able to perform this role successfully, the teacher needs to make selection of those content and environmental impacts that will encourage child's development. He must know "wisely and thoroughly the race-expression which is embodied in that thing we call the Curriculum" (Dewey, 1974a, p. 358) and to organize it in a way that will help the child to develop his abilities and his experience. The task of the teacher, then, is to "psyhologize" subject matters, which means to translate them into immediate experience that is significant and familiar to children. Therefore, the teacher is not concerned with the subject matter as such, but with subject matter as a related factor in a total and growing experience (Dewey, 1974a, p. 352). Guidance is not external imposition, warns Dewey, it is freeing the lifeprocess for its own most adequate fulfilment. But this does not mean that the child should be left entirely alone. Guidance also means selection of appropriate stimuli for instincts and impulses which it is desired to employ in the gaining of new experience (Dewey, 1974a, p. 348-349). So, the intervention and the control of the teacher is an integral part of the educational work, and his experience and maturity are essential in providing normal conditions for the child's development.

The role of the teacher to stimulate student's learning by experiencing brings a different conception of discipline. It is not identified with drill, which aim is uniform external modes of action, but it is understood as a power of control of the means necessary to achieve ends and to value and test them (Dewey, 1974d, p. 255). Hence, the discipline is not imposed by the teacher, but derives from student's learning and his need to control the process of attaining of desired goals. 
There is no doubt that in Dewey's theory teacher is indispensable figure in the process of education as the one who guide and nurture student's development by providing link between the subject matter and the student's developing experience. Realization of this task depends on teacher's abilities and efforts to adjust the school life to the intellectual and personal characteristics of each student, and to represent an "intelligent medium of action" (Dewey, 1974b, p. 205) who will be in possess of a sound knowledge of ethical and psychological principals, native tact and sympathy, and experience.

\section{Gardner on teachers' role}

Howard Gardner (1991) makes difference between two alternative ways of transmiting knowledge to the students. The main characteristic of the first one, so called "mimetic" education, is that students duplicated the desired behavior demonstrated by the teacher. This approach is focused on mastery of three Rs, and emphasizes basic skills and factual knowledge. The second approach is "transformative", where teacher serves as a facilitator, trying to evoke students' understandings. Students are encouraged to understand information, to solve problems and to work out their own ideas. This approach is oriented on individual invention of knowledge, transformation of past knowledge and on creative exploration. It is obvious that creativity approach is closer to Gardner' understanding of effective teaching, but he reflects on possibility to combine elements of both manners of transmiting knowledge. "One could value basic skills and yet seek to inculcate them through transformative methods- for example by having children learn to write by keeping their own journals or learn to compute by supervising their own little shopping centers." (Gardner, 1991, p. 120).

In accordance with the key points of the MI theory, teachers should approach topics through multiple entry points and plan time for students to engage in self-reflection, undertake self-paced work, interact in different ways or link their personal experience and feelings to the material being studied. They should continually shift methods from linguistic to musical, from spatial to bodily-kinesthetic, often combining intelligences in creative way. "Teachers seeking to utilize multiple intelligences theory in their classrooms must determine their students' strengths, weaknesses, and their combination of intelligences in order to provide meaningful learning experiences for them. The challenge is to figure out what these combinations are and how to best engage them." (Philips, 2010). Thematic instruction is another approach that is related to MI theory. Gardner recognizes the importance of teaching students from an interdisciplinary point of view. Even the teacher-centered teaching can use MI principles in a variety of ways designed to stimulate all intelligences. "The teacher who teaches with rhythmic emphasis (musical), draws pictures on the board to illustrate points (spatial), makes dramatic gestures while talking (bodily-kinesthetic), asks questions that invite spirited interaction (interpersonal), and includes references to nature in her lectures (naturalist) is using MI principles within a traditional teacher-centered perspective." (Armstrong, 2009, p.57).

\section{Dewey and Gardner on teachers'role}

Both Gardner and Dewey criticize the traditional role of a teacher as a dominant person in the classroom who through lecturing gives students portions of information that they should memorize and reproduce when needed. According to their opinion, the role of the teacher is defined within their understanding of child's development and experience. They both stress the individual approach in the process of teaching which means that teacher should recognize potentials, needs and interests of each student. Having in mind that students are engaged in classroom activities which are compatible to their individual abilities and interests, both authors develop similar concept of discipline that goes beyond the traditional understanding of classroom as a silent and static learning environment. Although Gardner didn't reflect on discipline in more elaborated way, his standpoint regarding this issue is positioned within the framework of active methods of learning and teaching, and creating an informal and relaxed atmosphere in a classroom. In comparison to Gardner, Dewey develops a positive and constructive concept of discipline which is not related to the role of the teacher, but to the student's learning and experience: "Discipline is a product, an outcome, an achievement, not something applied from without. All genuine education terminates in discipline, but it proceeds by engaging the mind in activities worthwhile for their own sake" (Armstrong, 1994). In general, both authors strive for a classroom management that creates environment in which students are likely to be less confused, 
frustrated or stressed out. As a result, teacher is not put in a position to invent behavioural "tricks" in order to provide optimal learning conditions.

\section{CONCLUSION}

The educational theory of the American philosopher and educator John Dewey and the theory of multiple intelligences of the American psychologist Howard Gardner are well known world-wide theories. They influenced the educational policy and practice in a variety of educational contexts in the time when were created and beyond. Both authors are strongly against the traditional way of teaching and learning and developed original concepts that initiated international movements that questioned the established school organization and instruction. This research is an attempt to compare some of the key points of their alternative educational models in order to identify compatible elements and intersections. It is focused on three fundamental aspects of the educational process: curriculum, learning and teaching methods and teacher's role. On the basis of the comparative analysis presented in the previous section, several conclusions can be derived.

- Both Gardner and Dewey criticize the teacher-centred and subject-centred classroom in which uniformed curriculum, passive methods of learning and traditional concept of discipline management were implemented.

- Both authors initiated educational reforms in the American school system and beyond.

- Both authors promote the idea that student should not be adjusted to demands of the school, but school should appreciate student's needs and potentials.

- Curriculum should be based on real life situations and related to the student's experience and nature.

- Instead of rigid and segmented curriculum, both strive for implementation of flexible and integrative curriculum.

- Instruction is process-oriented instead of content-oriented.

- Methods of learning and teaching should be individualized, active and inquiry-based aiming at developing students' higher order thinking.
- Teacher should create or adapt different teaching strategies that will be compatible to the students' individual differences and the material they study.

- Both authors stand up for positive and constructive concept of discipline and relaxed classroom atmosphere.

\section{Conflict of interests}

The authors declare no conflict of interest.

\section{REFERENCES}

Achkovska-Leshkovska, E. (2002). Gardnerovata teorija na inteligencijata i nejzinata implikacija vo nastavnata praktika [Gardner's theory of intelligence and its implication in teaching practice]. Godishen zbornik na Filozofskiot fakultet vo Skopje, 55, 79-103.

Armstrong, T. (1994). Multiple intelligences in the classroom. Alexandria, VA: Association for Supervision and Curriculum Development.

Armstrong, T. (2009). Multiple intelligences in the classroom (3rd ed.). Alexandria, VA: Association for Supervision \& Curriculum Development. Retrieved October 22, 2016, https://erwinwidiyatmoko.files.wordpress.com/2012/08/ multiple-intelligencies-in-the-classroom.pdf

Berube, M. R., \& Berube, C. T. (2007). The end of school reform. Rowman \& Littlefield.

Dewey, J. (1915). The school and society. Chicago: The University of Chicago Press.

Dewey, J. (1916a). 1966. Democracy and education. New York: Free Press, 578, 53-60.

Dewey, J. (1966b). Experience and Education. In Garforth, F.W. John Dewey: Selected Educational Writings. London: Heinemann.

Dewey, J. (1974a). The Child and the curriculum. In Archambauld, R.D.(Ed.). John Dewey on education. Chicago and London: The University of Chicago Press, 339-358.

Dewey, J. (1974b). What psychology can do for the teacher. In Archambauld, (Ed.). John Dewey on education. Chicago and London: The University of Chicago Press, 195-211.

Dewey, J. (1974c). My Pedagogic Creed. In Archambauld, (Ed.). John Dewey on education. Chicago and London: The University of Chicago Press, 425-439.

Dewey, J. (1974d). How we think. In Archambauld, (Ed.). John Dewey on education. Chicago and London: The University of Chicago Press, 242259.

Gardner, H. (1995). Reflections on multiple intelligences: Myths and messages. Phi Delta Kappan, 77, 200-209. Retrieved October 3, 2016, https:// learnweb.harvard.edu/WIDE/courses/files/Reflections.pdf

Gardner, H. (1983). Frames of mind: The theory of multiple intelligences. New York: Basic Books. 
(IJCRSEE) International Journal of Cognitive Research in Science, Engineering and Education Vol. 4, No.2, 2016.

Gardner, H. (1991). The unschooled mind: How children think, and how schools should teach. New York: Basic Books.

Gardner, H. (1993). Multiple intelligences: The theory in practice. New York: Basic Books.

Gardner, H. (1999). The disciplined mind: What all students should understand. New York: Simon \& Schuster.

Gardner, H. (2011). The theory of multiple intelligences: As psychology, as education, as social science. Address delivered at José Cela University on October, 29, 2011. Retrieved September 25, 2016, https://howardgardner01.files.wordpress. com/2012/06/473-madrid-oct-22-2011.pdf

Miovska-Spaseva, S. (2005). Pragmatistickata pedagogija i osnovnoto obrazovanie. [Pedagogy of pragmatism and elementary education]. Skopje: Selektor.

Phillips, H. (2010). Multiple Intelligences: Theory and Application.[Electronic version]. Perspectives in Learning: A Journal of the College of Education \& Health Professions,11(1). Retrieved October 3, 2016, https://perspectives.columbusstate.edu/ previous/1-MultipleIntelligences-print.pdf

Smith, M. K. (2002, 2008) 'Howard Gardner and multiple intelligences', the encyclopedia of informal education. Retrieved August 17, 2016, http:// infed.org/mobi/howard-gardner-multiple-intelligences-and-education

Tanner, L. N. (1997). Dewey's Laboratory School. Lessons for Today. Teachers College Press, New York. 